\title{
Pengaruh Pengawas Minum Obat Tablet Fe Pada Ibu Hamil Yang Anemia Terhadap Kenaikan Hb di Wilayah Kerja Puskesmas Padang Luar Kab. Agam
}

\author{
Lusina Novita ${ }^{a}$, Wedya Wahyu ${ }^{b}$, Tut Wuri Handayanic \\ aPuskesmas Padang Luar \\ ${ }^{a}$ Fakultas Keperawatan Universitas Andalas \\ ${ }^{\mathrm{c}}$ DKK Padang
}

\begin{abstract}
Anemia is still one of the major health problems in pregnant women in Indonesia. The most common cause of anemia in pregnant women are iron deficient, the impact of iron deficiency in pregnant women can be observed from fetal morbidity and mortality, as well as increased risk of low birth weight. The aim of this study was to determine the effect of Fe tablet medicine supervisor on pregnant women with anemia of Hb increase in work areas of Padang Luar public health center sub province Agam 2012. Design of study was quasi experiment with "Non-randomized control group pretest - posttest design". Samples were taken in Total sampling technique amount to 50 subjects who were divided into two groups, 25 groups of intervention and 25 group of control. In the intervention group involves the family as a supervisor to take medication tablet $F e$ while in the control group without medication tablet Fe supervisor. Analysis techniques used for the intervention and control groups using the Wilkolson test to see a significant. The statistical test result in intervention and control groups obtained the value $p=0.00(<0.05)$. Hence, from the results of this study, there was influence of medication supervision of anemia in pregnant women to increase Hb. It can be concluded that the involvement of family in supervise the medication can improve the obedience of mothers consuming Fe tablets, then increase $\mathrm{Hb}$ and decrease anemia incidence.
\end{abstract}

Key words: Fe tablets, pregnant women, anemia, $\mathrm{Hb}$

\begin{abstract}
Abstrak: Anemia masih merupakan salah satu masalah kesehatan utama pada ibu hamil di Indonesia. Penyebab paling umum dari anemia pada ibu hamil adalah kekurangan zat besi,dampak kekurangan zat besi pada wanita hamil dapat diamati dari angka kesakitan dan kematian janin, serta peningkatan resiko terjadinya berat badan lahir rendah. Tujuan penelitian ini untuk mengetahui pengaruh pengawas minum obat tablet Fe pada ibu hamil yang anemia terhadap kenaikan $\mathrm{Hb}$ di Wilayah kerja Puskesmas Padang Luar Kabupaten Agam Tahun 2012. Penelitian ini mengunakan desain quasi - eksprimen dengan mengunakan pendekatan "Non - randomized control group pretest - postest design". Teknik pengambilan sampel total sampling yaitu dengan jumlah sampel 50 orang yang dibagi dua kelompok, 25 kelompok intervensi dan 25 kelompok kontrol. Pada kelompok intervensi melibatkan keluarga sebagai pengawas minum obat tablet Fe sedang pada kelompok kontrol tanpa pengawas minum obat tablet Fe. Teknik analisa yang digunakan untuk kelompok intervensi dan kontrol yaitu mengunakan uji Wilkolson. Hasil uji stasistk kelompok intervensi dan kontrol didapatkan nilai $\mathrm{p}=0,00(<0,05)$. Maka dari hasil penelitian ini terdapat pengaruh pengawas minum obat pada ibu hamil yang anemia terhadap kenaikan $\mathrm{Hb}$. Maka dapat disimpulkan kerterlibatan keluarga dalam pengawas minum obat tablet $\mathrm{Fe}$ dapat meningkatkan kepatuhaan ibu dalam mengkonsumsinya sehingga dapat menaikan $\mathrm{Hb}$ dan menurunkan angka kejadian anemia.
\end{abstract}

Kata kunci: Obat tablet Fe, Ibu hamil, anemia, $\mathrm{Hb}$ 
Angka kematian ibu (AKI) merupakan salah satu indikator keberhasilan layanan kesehatan. Kematian dapat terjadi karena beberapa sebab diantara karena anemia. Anemia dalam kehamilan memberi pengaruh kurang baik bagi ibu, seperti abortus dan anemia dalam kehamilan juga memberi pengaruh kurang baik bagi hasil pembuahan (konsepsi) seperti: kematian mudigah, kematian perinatal, bayi lahir prematur, dapat terjadih cacat bawaan, dan cadangan besi yang kurang. Anemia merupakan sebab pontensial morbiditas serta mortalitas ibu dan anak (Ridwana, 2007 ).

Anemia merupakan kelainan hemat ologi yang paling sering dijumpai baik diklinik maupun di masyarakat. Anemia merupakan keadaan dimana masa eritrosit atau masa hemoglobin yang beredar tidak dapat memenuhi fungsinya, untuk mengankut oksigen bagi jaringan tubuh.Hemoglobin merupakan salah satu komponen eritrosit yang berfungsi sebagai alat angkut dapatoksigen. roses pembentukan eritrosit membutuh kan bahan diantaranya zat besi. Eritrosit hidup dan beredar dalam tepi rata -rata selama 120 hari. (Bakta, 2006).

Metabolisme zat besi dalam tubuh manusia berfungsi untuk sintesis protein yang membawa oksigen, yaitu hemoglobin serta mioglobin dalam tubuh, dan untuk sintesis enzim yang mengandung zat besi dan turut serta dalam reaksi perpindahaan elektron serta reaksi oksidasi-reduksi. Penyerapan terjadi diduodenum, kemudian zat besi yang diserap dibawa melalui membran mukosa serta serosa kedalam darah, protein pembawa (transferin) yang ada di dalam plasma menyangkut kedalam sel atau ke Sum-sum tulang bagi keperluan eritroposis (Gibney, dkk. 2008).

Penyebab paling umum dari anemia pada kehamilan adalah kekurangan zat besi. Kebutuhan akan zat besi selama kehamilan meningkat .Peningkatan ini dimaksud kan untuk memasok kebutuhan janin dan kebutuhan ibu hamil sendiri. Hal ini penting dilakukan pemeriksaan untuk anemia pada kunjungan pertama kehamilan. Bahkan jika tidak mengalami anemia pada kunjungan pertama, masih mungkin terjadi anemia pada kehamilan selanjutnya. Untuk pencegahannya dengan memberi suplementasi zat besi, yang mana biasanya diberikan secara rutin pada wanita hamil untuk mencegah penipisan simpanan besi tubuh untuk mencegah anemia (Proverawati, 2011).

Prevalensi anemia defesiensi besi menyerang lebih dari 2 milyar penduduk di dunia. Dinegara berkembang terdapat 370 juta wanita yang menderita anemia. Ratarata lebih tinggi pada ibu hamil (51\%), wanita tidak hamil (41\%). Di India terdapat sekitar $(88 \%)$ ibu hamil yang menderita anemia, di Asia ditemukan (60\%) wanita yang mengalami anemia (Gibney, dkk. 2008).

Anemia pada ibu hamil masih merupakan salah satu masalah kesehatan di Indonesia, dimana angka kematian ibu hamil yang cukup tinggi penyebab utama anemia. Bila prevalensi anemia diatas $40 \%$ maka akan terjadi kematian ibu sebanyak 18 ribu per tahun yang disebabkan pendaharan setelah melahirkan. Ini kondisi dengan estimasi $3-7 \%$ ibu meninggal karena menderita anemia berat dan sebesar $20-40 \%$ ibu meninggal karena penyebab langsung anemia (Depkes 2007).

Anemia gizi masih merupakan salah satu masalah gizi yang utama di indonesia. Dampak kekurangan zat besi pada wanita hamil dapat diamati dari besarnya angka kesakitan dan kematian maternal, peningkatan angka kesakitan dan kematian janin, serta peningkatan resiko terjadinya berat badan lahir rendah. Penyebab utama kematian martenal antara lain pendarahan pascapartum (disamping eklampsia dan penyakit infeksi) dan plasenta previa (Arisman, 2009).

Angka anemia kehamilan di Indonesia menunjukkan nilai yang cukup tinggi yang berkisar $41 \%$, pemerintah telah berusaha melakukan tindakan pencegahan dengan memberikan tablet tambah darah (tablet $\mathrm{Fe}$ ) pada ibu hamil yang dibagikan 
pada waktu memeriksakan kehamilan, akan tetapi prevalensi anemia pada ibu hamil masih juga tinggi. Pemeriksaan kadar hemoglobin yang dianjurkan dilakukan pada trimester pertama dan ketiga kehamilan, sering kali hanya dapat dilaksanakan pada trimester ketiga saja karena kebanyakan ibu hamil baru memeriksa kehamilannya pada trimester kedua kehamilan, sehingga penanganan anemia pada kehamilan menjadi terlambat dengan akibat berbagai komplikasi yang mungkin terjadi karena anemia. Kriteria anemia yang digunakan sesuai dengan kriteria WHO yaitu < 11 gr \% (Yone, 2010).

Mengingat dampak anemia dapat menurunkan kualitas SDM di indonesia, maka perlu penanggulangan kekurangan zat besi pada ibu hamil dengan segera.Oleh sebab itu pemerintah indonesia mulai menerapkan suatu program penambahaan zat besi sekitar 20 tahun yang lalu program ini dilaksana kan dengan harapan setiap ibu hamil secara teratur memeriksakan diri kepuskesmas atau posyandu selama masa kehamilannya. Tablet besi dibagikan oleh petugas kesehatan kepada ibu hamil secara gratis (Depkes, 2008).

Untuk meningkat kepatuhan ibu dalam mengkonsumsi tablet fe petugas kesehatan harus mengikut sertakan keluarga dalam pengawasan makan obat ,pengawasan minum obat merupakan kegiatan yang dilakukan untuk menjamin kepatuhaan minun obat sesuai dengan dosis dan jadwal seperti yang telah ditetapkan (Maulana,2008)

Pemantauan minum obat (PMO) menurut depkes RI (1999) adalah seseorang yang di tunjuk dan dipercaya untuk mengawasi dan memantau penderita dalam meminum obat secara teratur dan tutas, PMO bisa berasal dari keluarga, tetangga, kader, tokoh masyarakat atau petugas kesehatan. Tugas pengawasan minum obat dirumah diantaranya ,mengawasi minum obat harian dirumah, mencatat obat yang telah diminum,dan mencatat keluhan yang dialami penderita,ikut serta dalam pengambilan obat,memberi motivasi supaya tidak terjadih kegagalan minum obat serta menjadih penyuluhan kesehatan (Krisnawati, 2010).

Keluarga dapat menjadih faktor yang sangat berpengaruh dalam menentukan keyakinan dan nilai kesehatan individu serta dapat juga menentukan tentang program pengobatan yang dapat mereka terima .Keluarga juga memberikan dukungan dan membuat keputusan mengenai perawat dari angota yang sakit serta menentukan keputusan untuk mencari dan memenuhi anjuran pengobatan (Hendrawati, 2008).

Berdasarkan profil dinas kesehatan Sumbar setidaknya $68 \%$ dari seluruh kehamilan Ibu hamil masih rawan terkena anemia zat besi. Jumlah ibu hamil yang mendapat kan Fe1 sebanyak 89.911 per 103.481(86,89\%) dan ibu hamil yang mendapatkan pelayanan $\mathrm{Fe} 3$ sebanyak 78.308 per $103,481(75.67 \%)$ orang Jumlah ibu dengan kehamilan berisiko tinggi sebanyak $15.137(14,21 \%)$ salah satu penyebabnya adalah anemia (Dinkes Sumbar, 2008).

Berdasarkan profil dinas kesehatan Agam tahun 2010, jumlah sasaran ibu hamil di kabupaten Agam adalah 10.889 orang. Selama tahun 2010 tersebut, Ibu Hamil mendapat tablet fe1 (75.8\%) sedangkan untuk tablet $\mathrm{Fe} 3$ adalah $(68.9 \%)$. Pelayanan kesehatan ibu hamil dengan pemeriksaan $\mathrm{Hb}$ selama tahun 2010 berjumlah sebanyak 8008 ibu hamil dengan hasil pemeriksaan di dapatkan jumlah ibu hamil yang mengalami anemia $(\mathrm{Hb}<$ $11 \mathrm{~g} / \%)$ yaitu sebanyak 2,131 (26,6\%) s (Dinkes Agam 2010).

Prevalensi Ibu Hamil Anemia di kabupaten Agam 2011, diketahui dari 22 Puskesmas yang ada di kabupaten Agam, bahwa Pukesmas Palembayan urutan pertama. Jumlah ibu hamil anemia $(36,1 \%)$, kemudian Puskesmas. Bawan (31,5\%), kemudian urutan ke tiga Puskesmas Padang Luar, yaitu jumlah ibu hamil anemia dari 643 ibu hamil, yang anemianya 205 $(31,1 \%)$ (Dinkes, 2011). 
Berdasarkan data jumlah ibu hamil dari laporan Puskesmas Padang tahun 2010. Sebesar 749 orang ibu hamil, terdapat 260 orang anemia yang $\mathrm{Hb}$ nya $<11 \mathrm{~g} / \mathrm{dl}$ $(34.7 \%)$. Bumil yang mendapat $\mathrm{Fe} 490$ bumil (65,4\%). Berdasarkan data puskesmas Padang Luar dari tahun 2011 jumlah ibu hamil 643 orang terdapat 205 orang yang anemia $(31,8 \%)$.

Prevalensi Anemia gizi besi pada ibu hamil di 7 Nagari di wilayah kerja puskesmas pada luar dari bulan Januari Oktober 2011. Nagari Sungai Tanang merupakan daerah yang terbanyak ibu hamil yang anemia (46,4\%), Kubang Putiah (30,3\%), Ladang Laweh $(29,4 \%)$, Padang Luar (29 \%), Pakan Sinayan (25,2\%), Taluak (24,7\%), Nagari Cingkariang memiliki jumlah anemia terendah dari 86 ibu hamil yang anemia 20 Orang (23\%). Berdasarkan laporan puskesmas bulan januari 2012 ibu hamil yang anemia, $\mathrm{Hb}<11 \mathrm{~g} / \%$ sebanyak 50 Orang.

Dalam program pemberiaan tablet fe, dinas kesehatan Kab. Agam, telah melakukan berbagai upaya untuk meningkat kan pencapaian program, Diantara nya mengatasi anemia pada kehamilan yaitu dengan pemberian tablet Fe 90 tablet minimal selama kehamilan,yang mana setiap ibu hamil wajib diberi tablet $\mathrm{Fe}$, tapi kenyataan dilapangan anemia pada ibu hamil masih cukup tinggi, penyebab diantaranya ketidakpatuhan ibu hamil dalam mengkonsumsi tablet fe, dan dukungan keluarga yang kurang dalam pemantauan makan obat tablet Fe.

Pada tahun 2010 prevalensi anemia di puskesmas padang Luar (36\%)dan pada tahu 2011( 31,\%). Walaupun pada tahun
2011 telah dilakukan pemberiaan tablet $\mathrm{Fe}$ 3X1 berhari terutama pada ibu hamil yang anemia yang $\mathrm{Hb}$ nya $<10 \mathrm{~g} / \%$, tapi pemberian ini tidak dilibat kan keluarga dalam (PMO) sehingga pencapaian nya tidak sesuai yang diinginkan. Karna efek yang ditimbulkan seperti mual terutama ibu hamil dalam kehamilan trimester 1, sehinnga menyebab kan ketidak patuhan dalam mengkonsumsi tablet $\mathrm{Fe}$, dan juga kurang nya dukungan dari keluarga

Berdasarkan hasil wawancara dengan 10 orang ibu hamil diwilayah kerja puskesmas padang luar di peroleh informasi ternyata dari 8 orang ibu hamil tidak mengetahui manfaat tablet fe bagi dirinya maupun janinnya, dan selama kehamilan setiap tablet fe yang diberikan jarang di konsumsi, karena ketidaktahuan manfaat, efek samping, cara dan waktu mengkonsumsi, Peneliti juga melakukan wawancara terhadap keluarga terutama suami ibu hamil, Suami mengatakan bahwa tidak pernah memperhatikan istrinya dalam mengkonsumsi tablet fe, karena ketidaktahuannya manfaat tablet Fe bagi istri dan bayi dalam kandungan istrinya.

Berdasar hasil wanwacara dengan pimpinan puskesmas padang luar bahwa dalam pemberiaan tablet fe. Puskesmas belum melakukan pemantauan makan obat tablet fe pada ibu hamil yang melibatkan keluarga terutama suami. Pemberian tablet $\mathrm{Fe}$ hanya langsung diberikan pada ibu hamil tanpa melibat kan suami dan keluarga.Sehingga dalam pemberiaan tablet Fe pada ibu tidak menunjukan kenaikan $\mathrm{Hb}$ yang berarti, sehingga kasus anemia masih banyak ditemukan dipuskesmas Padang luar, walaupun program tablet Fe menjadi prioritas utama dalam mencegah anemia, tapi menjadi hal yang sia- sia.

randomized Control Group Pretes-Postest Design". Teknik pengambilan sampel adalah Total Sampling Seluruh ibu hamil anemia yag Hbnya $<11 \mathrm{~g} / \mathrm{dl}$. Jumlah sampel 50 orang jumlah seluruh sampel 
dibagi dua dimana 50\% (25 orang ) dijadikan kelompok eksperimen dan 50\%

\section{HASIL DAN PEMBAHASAN}

Analisa Univariat digunakan untuk menjelaskan atau mendeskripsikan variabel penelitian guna memperoleh
(25 0rang) sebagai kelompok kontrol

gambar karakteristik masing-masing variabel sebelum dan sesudah di beri tablet Fe.

Tabel 1. Distribusi frekuensi karakteristik ibu hamil anemia yang mendapat tablet fe di Puskesmas Padang Luar tahun 2012

\begin{tabular}{llccc}
\hline No & \multicolumn{1}{c}{ Status Anemia } & \multicolumn{2}{c}{ Mendapat Tablet Fe } \\
\hline & & $\mathbf{F}$ & $\mathbf{\%}$ \\
$\mathbf{1}$ & Tidak Anemia & - & - \\
$\mathbf{2}$ & Anemia Ringan & 45 & 90 \\
$\mathbf{3}$ & Anemia Sedang & 5 & 10 \\
$\mathbf{4}$ & Anemia Berat & - & - \\
& Jumlah & 50 & 100 \\
\hline
\end{tabular}

Pada tabel 1.menjelaskan dari 50 orang responden yang mendapat tablet $\mathrm{Fe}$ yang anemia ringan 45 orang $(90 \%)$,yang anemia sedang 5 orang (10\%).

Tabel 2. Distribusi Frekuensi Karakteristik Responden Berdasarkan Kepatuhan Minum Obat Tablet FE Oleh Ibu Hamil Anemia Diwilayah Kerja Puskesmas Padang Luar Kab.Agam Tahun 2012

\begin{tabular}{|c|c|c|c|c|c|}
\hline \multirow[t]{2}{*}{ No } & \multirow[t]{2}{*}{ Kepatuhan } & \multicolumn{2}{|c|}{$\begin{array}{c}\text { Kelompok intervensi } \\
(\mathrm{PMO})\end{array}$} & \multicolumn{2}{|c|}{$\begin{array}{c}\text { Kelompok kontrol } \\
\text { (Tanpa PMO) }\end{array}$} \\
\hline & & $\mathbf{f}$ & $\%$ & $\mathbf{f}$ & $\%$ \\
\hline 1 & $\begin{array}{l}\text { Minum obat teratur / } \\
\text { habis }\end{array}$ & 24 & 96 & 6 & 24 \\
\hline 2 & $\begin{array}{l}\text { Minum obat tidak } \\
\text { teratur/ tidak habis }\end{array}$ & 1 & 4 & 11 & 44 \\
\hline 3 & Tidak minum obat & - & - & 8 & 32 \\
\hline
\end{tabular}

Tabel 2 menjelaskan tentang kepatuhan responden dalam mengkonsumsi tablet fe .pada kelompok intervensi $24(96 \%)$, responden ninun obat teraturdan habis,sedang kan pada kelompok kontrol (44\%) responden tidak teratur minum obat/ tidak habis, $(32 \%)$ responden tidak meminum obat, dan $(24 \%)$ meminum obat secara teratur.

Tabel. 3. Berbedaan Kenaikan Hb pada kelompok intervensi dan kontrol hamil yang anemia di puskesmas padang luar Kab .Agam 2012.

pada ibu

\begin{tabular}{ccccccccccc}
\hline & \multicolumn{4}{c}{ Kelompok Intervensi(PMO) } & \multicolumn{5}{c}{ Kelompok Kontrol (Tanpa PMO) } \\
\cline { 2 - 11 } No & $\begin{array}{c}\text { Hb } \\
\text { Sblm }\end{array}$ & $\begin{array}{c}\text { Hb } \\
\text { Sda }\end{array}$ & Selisih & $\begin{array}{c}\text { Usia } \\
\text { Khm }\end{array}$ & pmo & $\begin{array}{c}\text { Hb } \\
\text { Sblm }\end{array}$ & $\begin{array}{c}\text { Hb } \\
\text { sda }\end{array}$ & Selisih & $\begin{array}{c}\text { Usia } \\
\text { Khml }\end{array}$ & $\begin{array}{c}\text { Tanpa } \\
\text { (pmo) }\end{array}$ \\
\hline $\mathbf{1}$ & 9 & 9,6 & 0,6 & 2 & Suami & 10 & 10,2 & 0,2 & 2 & - \\
$\mathbf{2}$ & 9,3 & 10 & 0,7 & 2 & Suami & 9,9 & 9,9 & 0 & 2 & - \\
$\mathbf{3}$ & 10 & 10,3 & 0,3 & 2 & Suami & 10,5 & 10 & $-0,5$ & 2 & - \\
$\mathbf{4}$ & 10 & 11 & 1 & 3 & Suami & 10 & 10,3 & 0,3 & 3 & - \\
$\mathbf{5}$ & 9,8 & 10,4 & 0,6 & 2 & Suami & 10,7 & 10,9 & 0,2 & 2 & - \\
$\mathbf{6}$ & 10,4 & 11 & 0,6 & 2 & Suami & 9,8 & 9 & $-0,8$ & 2 & - \\
\hline
\end{tabular}




\begin{tabular}{ccccccccccc}
\hline $\mathbf{7}$ & 10,5 & 11 & 0,5 & 3 & Suami & 10 & 9,8 & $-0,2$ & 3 & - \\
$\mathbf{8}$ & 7,4 & 7,8 & 0,4 & 2 & Suami & 10,2 & 9,7 & $-0,5$ & 2 & - \\
$\mathbf{9}$ & 10,7 & 11 & 0,3 & 2 & Suami & 10,8 & 11 & 0,2 & 2 & - \\
$\mathbf{1 0}$ & 10 & 11 & 1 & 3 & Suami & 10,8 & 10 & $-0,8$ & 3 & - \\
$\mathbf{1 1}$ & 10 & 10,4 & 0,4 & 2 & Suami & 10 & 9,3 & $-0,7$ & 2 & - \\
$\mathbf{1 2}$ & 8 & 8,9 & 0,9 & 2 & Suami & 10 & 10.2 & 0,2 & 2 & - \\
$\mathbf{1 3}$ & 10,6 & 11 & 0,4 & 3 & Suami & 10 & 10,3 & 0,3 & 2 & - \\
$\mathbf{1 4}$ & 7,2 & 7,6 & 0,4 & 2 & Suami & 10,1 & 10,5 & 0,4 & 2 & - \\
$\mathbf{1 5}$ & 9,5 & 10,4 & 0,9 & 2 & Suami & 10 & 10,2 & 0,2 & 3 & - \\
$\mathbf{1 6}$ & 10 & 11 & 1 & 2 & Suami & 9,8 & 9 & $-0,8$ & 3 & - \\
$\mathbf{1 7}$ & 9,8 & 10,1 & 0,3 & 2 & Suami & 10 & 10,1 & 0,1 & 2 & - \\
$\mathbf{1 8}$ & 10 & 11 & 1 & 3 & Suami & 10 & 9,8 & $-0,2$ & 2 & - \\
$\mathbf{1 9}$ & 7,8 & 8,1 & 0,3 & 2 & Suami & 10,5 & 10,7 & 0,2 & 2 & - \\
$\mathbf{2 0}$ & 10 & 11 & 1 & 2 & Suami & 10,8 & 10,1 & $-0,7$ & 2 & - \\
$\mathbf{2 1}$ & 10 & 11 & 1 & 2 & Suami & 10 & 9,5 & $-0,5$ & 2 & - \\
$\mathbf{2 2}$ & 10 & 10,3 & 0,3 & 2 & Suami & 9,8 & 9 & $-0,8$ & 2 & - \\
$\mathbf{2 3}$ & 8 & 8,5 & 0,5 & 2 & Suami & 10 & 10,3 & 0,3 & 2 & - \\
$\mathbf{2 4}$ & 9 & 10,5 & 0,5 & 2 & Suami & 9,8 & 10 & 0,2 & 2 & - \\
$\mathbf{2 5}$ & 10,4 & 9,8 & $-0,6$ & 2 & Ortu & 10 & 9,8 & $-0,2$ & 2 & - \\
\hline
\end{tabular}

Tabel 4. memperlihatkan bahwa kelompok interensi terjadi peningkatan $\mathrm{Hb}$, sebanyak 24 orang responden mengakui kenaikan $\mathrm{Hb}$ dari $0.3-1 \mathrm{gr} \%$, dan hanya 1 orang yang mengalami penurunan,pada kelompok kontrol yang tidak dilakukan $\mathrm{PMO}, 12$ orang $\mathrm{Hb}$ meningkat, 12 orang terjadi penurunan dan 1 orang tidak berubah

Tabel 4. Distribusi Frekwensi Ibu Hamil Berdasarkan Kreteria Anemia Sebelum Dan Sesudah Mendapatkan Tablet Fe Diwilayah Kerja Puskesmas Padang Luar Kab. Agam Tahun 2012

\begin{tabular}{|c|c|c|c|c|c|c|c|c|c|}
\hline \multirow{3}{*}{ No } & \multirow{3}{*}{$\begin{array}{l}\text { Status } \\
\text { Anemia }\end{array}$} & \multicolumn{4}{|c|}{ Kelompok Intervensi (PMO) } & \multicolumn{4}{|c|}{$\begin{array}{c}\text { Kelompok Kontrol } \\
\text { (Tanpa PMO) }\end{array}$} \\
\hline & & \multicolumn{2}{|c|}{$\begin{array}{c}\text { HB Awal } \\
\text { (pretes) }\end{array}$} & \multicolumn{2}{|c|}{$\begin{array}{c}\text { HB } \\
\text { Akhir } \\
\text { (postes) }\end{array}$} & \multicolumn{2}{|c|}{$\begin{array}{l}\text { HB Awal } \\
\text { (pretes) }\end{array}$} & \multicolumn{2}{|c|}{$\begin{array}{c}\text { HB } \\
\text { Akhir } \\
\text { (postes) }\end{array}$} \\
\hline & & $\mathbf{f}$ & $\%$ & $\mathbf{f}$ & $\%$ & $\mathbf{f}$ & $\%$ & $\mathbf{f}$ & $\%$ \\
\hline \multirow{5}{*}{$\begin{array}{l}\mathbf{1} \\
\mathbf{2} \\
\mathbf{3} \\
\mathbf{4}\end{array}$} & Tidak anemia & & & 10 & 40 & & & & \\
\hline & Anemia ringan & 20 & 80 & 10 & 40 & 25 & 100 & 25 & 100 \\
\hline & Anemia sedang & 5 & 20 & 5 & 20 & & & & \\
\hline & Anemia berat & & & & & & & & \\
\hline & Jumlah & 25 & 100 & 25 & 100 & 25 & 100 & 25 & 100 \\
\hline
\end{tabular}

Pada tabel 5 diatas pada kelompok intervensi pada $\mathrm{Hb}$ awal (pretest) staatus anemia yang terbanyak anemia ringan 20 orsng (80\%), anemia sedang 5 orang (20\%). Pada Hb akhir (postest) tidak anemia10 orang (40\%) status anemia ringan menurun menjadih 10 orang (40 $\%)$,dan anemia sedang tetap 5orang (20\%). Sedang pada kelompok kontrol pada HB awal status Anemia ringan 25 orang $(100 \%)$ dan $\mathrm{Hb}$ akhir status anemia ringan tetap 25 orang $(100 \%)$. 
Setelah data diolah dengan analisa Univariat selanjutnya dilakukan pengolahan data dengan Analisa Bivariat dengan tujuan untuk mengetahui pengaruh variabel independen terhadap variabel dependen yang telah diteliti sebelum dilakukan uji hipotesis. Pertama peneliti melakukan uji normalitas dengan menggunakan uji shapiro-wilk, setelah dilakukan uji normalitas ternyata sebaran data tidak normal maka dilakukan uji Wilcoxon. Setelah itu untuk membandingkan antara kelompok intervensi dan kontrol, maka dilakukan uji mann - whitney. Apabila terdapat perbedaan antara kelompok intervensi dan kontrol dengan tingkat kemaknaan $\mathrm{P}<$ 0,05 berarti terdapat perbedaan yang bermakna antara kelompok intervensi dengan kelompok kontrol.

Tabel 5. Pengaruh Pemberian Tablet Fe pada Ibu Hamil yang Anemia Terhadap Kenaikan Hb pada Kelompok Intervensi di Wilayah kerja Puskesmas Padang Luar Kab. Agam Tahun 2012

\begin{tabular}{ccccccc}
\hline $\begin{array}{c}\text { Kelompok } \\
\text { intervensi }\end{array}$ & Mean & $\mathrm{N}$ & $\begin{array}{c}\text { Std } \\
\text { Deviation }\end{array}$ & Minimum & Maxsimum & $\mathrm{P}$ \\
\hline $\begin{array}{c}\text { Hb awal } \\
\text { (pretes) }\end{array}$ & 9,4960 & 25 & 1,02733 & 7,20 & 10,70 & \\
$\begin{array}{c}\text { Hb akhir } \\
\text { (postes) }\end{array}$ & 10,0880 & 25 & 1,08678 & 7,60 & 11 & 0,000 \\
\hline
\end{tabular}

Pada tabel 5 diatas dapat dilihat perbedaan nilai mean pada $\mathrm{Hb}$ awal (Pretest 9,4960 sedang kan $\mathrm{Hb}$ akhir (postest) nilai meannya 10,0880. Dengan standar deviasi pretest 1,02733 dan postest 1,08678 ,sedang nilai minimum pretest 7,20 dan postest 7,60 dan nilai maxsimum10,70 pretest dan 11 postes. Hasil uji statistik dengan mengunakan uji Wilcoxon didapat nilai $\mathrm{p}=0,00(\mathrm{p}<0,05)$. Berarti dapat disimpulkan terdapat adanya pengaruh pemberian tablet Fe terhadap kenaikan $\mathrm{Hb}$ dengan melibatkan keluarga sebagai PMO (Pengawasan Minum Obat).

Tabel 6. Pengaruh Pemberian Tablet Fe pada Ibu Hamil yang Anemia terhadap Kenaikan Hb pada Kelompok Kontrol di Wilayah kerja Puskesmas Padang Luar Kab. Agam Tahun 2012

\begin{tabular}{ccccccc}
\hline $\begin{array}{c}\text { Kelompok } \\
\text { kontrol }\end{array}$ & Mean & $\mathrm{N}$ & $\begin{array}{c}\text { Std } \\
\text { Deviation }\end{array}$ & Minimum & Maxsimum & $\mathrm{P}$ \\
\hline $\begin{array}{c}\text { Hb awal } \\
\text { (pretes) }\end{array}$ & 10,0600 & 25 & 0,26300 & 9,80 & 10,80 & 0,181 \\
$\begin{array}{c}\text { Hb akhir } \\
\text { (postes) }\end{array}$ & 9,9160 & 25 & 0,44598 & 9 & 10,50 & \\
\hline
\end{tabular}

Pada tabel 6 diatas dapat dilihat perbedaan nilai mean pada $\mathrm{Hb}$ awal (Pretest 10,0600 sedang kan $\mathrm{Hb}$ akhir (postest) nilai mean nya 9,9160 Dengan standar deviasi pretest 0,26300 dan postest 0,44598 ,sedang nilai minimum pretest 9,80 dan postest 9 dan nilai maxsimum10,80 pretest dan 10,50 postes. Hasil uji statistik dengan mengunakan uji Wilcoxon didapat nilai $\mathrm{p}=0,00(\mathrm{p}>0,05)$. Berarti dapat disimpulkan tidak ada pengaruh pemberian tablet Fe terhadap kenaikan $\mathrm{Hb}$ 
Dalam meningkatkan kepatuhan ibu hamil dalam mengkonsumsi tablet Fe petugas kesehatan harus mengikut sertakan keluarga sebagai pengawas minum obat tujuanya supaya ibu hamil dapat patuh dalam mengkonsumsi tablet tablet fe sehinga dengan adanya Pengawas minum obat pada ibu hamil anemia bisa menimgkatkan kepatuhan ibu dalam mengkonsumsi tablet fe sehingga dengan mengkonsumsi tablet fe penuh bisa meningkatkan kenaikan $\mathrm{Hb}$ pada ibu hamil.sehingga prepalensi angka kejadian anemia dapat diturunkan.

Pada kelompok intervensi yang melibat kan keluarga dalam pengawas minum obat (PMO), dengan adanya pengawas minum obat ini bisa memperkuat keinginan ibu hamil dalam memgkonsumsi tablet fe.Sehinga peran keluarga dalam pengawas minum obat tablet fe bisa meningkatkan motivasi keinginan yang kuat dalam diri ibu hamil untuk mengkonsumsi tablet fe, sehinga denga adanya keinginan yang kuat dalam diri ibu hamil tersebut bisa meningkat kan kepatuhan ibu dalam mengkonsumsi tablet fe.

Setelah mengkonsumsi Fe selama satu bulan dengan pemberian $1 \mathrm{x} 1$ berhari sebanyak 30 tablet dengan melibatkan keluarga sebagai pengawas minum obat, pada 25 responden kelompok perlakuan 24 orang mengalami kenaikan $\mathrm{Hb}$ dan 1 orang mengalami penurunan ,kenaikan $\mathrm{Hb}$ berkisar antara 0,3 sampai $1 \mathrm{~g} \%$ dalam mengkonsumsi Fe selama satu bulan. Pengaruh keluarga sebagai Pengawas minum dapat meningkatkan kepatuhan ibu hamil dalam mengkonsumsi tablet $\mathrm{Fe}$ dilihat darikenaika $\mathrm{Hb}$.

Pada responden yang mengalami kenaikan $\mathrm{Hb}$ karna selama mengkonsumsi tablet fe satu bulan dilibatkan keluarga sebagai pengawas minum obat (PMO). mendapat dukungan keluarga yang penuh sebagai pengawas minum obat disini fungsi PMO mengingat kan minum obat tiap hari,dan memberi dukungan dan motivasi pada ibu hamil sehingga meningkat kepatuhan ibu dalam mengkonsumsi tablet $\mathrm{Fe}$. satu orang responden pada kelompok perlakuan yang tidak mengalami kenaikan $\mathrm{Hb}$ karna kurang nya dukungan keluarga dalam mingingatkan untuk minum obat tablet $\mathrm{Fe}$ setiap hari dan kurang nya kepatuhan pasien dalam mengkonsumsi tablet Fe.

Pengawas minun obat yang dilibat kan dalam keluarga dari 25 orang bresponden 24 responden yang menjadih PMO adalah suami dari ibu hamil yang menjadih responden.Dilihat dari kenaikan $\mathrm{Hb}$ pada kelompok intervensi yang pengawas minum obatnya suami dapat meningkatkan kepatuhan ibu dalam mengkonsumsi tablet $\mathrm{Fe}$,sehingga meningkatkan kenaikan $\mathrm{Hb}$ pada ibu hamil yang sinifikan, dibandingkan pada satu orang ibu hamil yang pengawas minum obat nya ortu dari ibu hamil sehingga kepatuhan ibu dalam mengkonsumsi fe juga berkurang sehingga terjadih penurunan $\mathrm{Hb}$.Kerterlibatan suami sangat penting sebagai pengawas minum obat tablet fe semenjak awal mengkonsumsi tablet fe sehinnga berguna uantuk menjaga secara emosional merasa tenang dan yakin dalam mengkonsumsi tablet Fe.

Pada kehamilan terjadi peningkatan akan kebutuhan zat besi sehinga pada waktu hamil ibu sangat dianjurkan untuk mengkonsumsi tablet fe yang tujuan nya untuk mencegah anemia pada ibu hamil .Pada usia kehamilan trimester II dan III terjadih peningkatan kebutuhan zat besi disebab kan karna terjadihnya hemodialisis pada kehamilan sehingga membutuhkan zat besi yamg banyak untuk pembentukan $\mathrm{Hb}$,yang ditujukan untuk janin dan untuk ibu hamil sendiri,dengan makanan yang di konsumsi sehari tidak cukup untuk memenuhi kebutuhan zat besi,dan untuk itu tablet $\mathrm{Fe}$ sangat dibutuhkan selama kehamilan .Dengan efek samping tablet fe yang sangat mengangu pada ibu hamil sehinnga pentingnya pengawas minum obat yang melibatkan keluarga untuk memantau ,mencatat dan mengingatkan dan memberi dukungan pada ibu hamil 
sehungga menimgkatkan kepatuhan ibu dalam mengkonsumsi Fe.

Pada kelompok intervensi yang melibatkan keluarga sebagai pengawas minum obat (PMO) tablet fe dengan usia kehamilan yang terbanyak pada trimester ke II sebanyak 20 responden $(80 \%)$ terimester III 5 (20\%) mengalami kenaikan $\mathrm{Hb}$ dari 0,3 sampai $1 \mathrm{~g} \%$. Walaupun dengan usia kehamilan pada trimester II dan III tingkat kebutuhan zat besi meningkat pada usia kehamilan ini banyak ibu hamil yang mengalami anemia .dengan adanya pengawas minum obat (PMO) sehimgga bisa meningkatkan $\mathrm{Hb}$ ibu hamil,disebabkan karna kepatuhan dalam mengkonsumsi tablet fe.Sedang pada kelompok kontrol tanpa pengawas minum obat (PMO) terjadi penurunan $\mathrm{Hb}$ yang banyak pada responden yaitu 12 0rang,dan kenaikan $\mathrm{Hb}$ pada responden kelompok kontrol juga 12 orang tapi kenaikan nya tidak begitu sinikfikan dinbandingkan kelompok yang melibatkan keluarga sebagai (PMO).Karna pada kelompok kontrol yang tidak melibatkan keluarga sebagai (PMO) usia kehamilan pada responden paling banyak trimester II dan III,pada usia kehamilan ini terjadih peningkatan akan kebutuhan zat besi karna pada kehamilan terjadi hemodialisis.

Dukungan keluarga terutama suami sangat lah penting selama kehamilan untuk menjaga secara emosional merasa tenang percaya diri menjalankan kehamilan dan lebih bahagia menjalani kehamilan. Untuk meningkatkan kepatuhaan ibu untuk mengkonsumsi tablet fe keluarga sangat mempunyai peranan dalam memantau, menginggatkan ibu dalam mengkonsumsi tablet Fe.

Menurut Depkes RI (1999). Pemantauan minum obat adalah seorang yang ditunjuk dan dipercaya untuk mengawasi dan memantau penderita dalam mengkonsumsi obat secara teraratur dan tuntas. Tugas pengawas obat dirumah diantaranya, mengawasi minum obat harian dirumah, mencatat obat yang diminum, dan mencatat keluhaan yang dialami penderita, ikut serta dalam pengambilan obat,dan memberi motivasi (Krisnawati,2010).

Kalau dilihat dari status anemia pada tabel 4. Kelompok intervensi yang melibatkan keluarga sebagai (PMO) sebelum pemberian tablet $\mathrm{Fe}$ anemia ringan 20 orang $(80 \%)$ kemudian terjadih penurunan pada $\mathrm{Hb}$ akhir setelah mengkonsumsi tablet $\mathrm{Fe}$ menjadih 10 orang (40\%). Pada pemeriksaan Hb akhir status anemia ringan berubah menjadih tidak anemia atau $\mathrm{Hb}$ kembali normal $11 \mathrm{~g} \%$ sebanyak 10 orang responden atau $(40 \%)$ status anemia sedang berdasarka kreteria anemia pada $\mathrm{Hb}$ awal dan $\mathrm{Hb}$ akhir tetap sama.

Pada kelonpok kontrol (Tanpa PMO) setelah pemberian Tablet Fe selama satu bulan 12 orang responden $\mathrm{Hb}$ nya naik sedang 12 orang lagi mengalami penurunan 1orang tetap. Kenaikan $\mathrm{Hb}$ pada kelompok respondem berkisar antra 0,1 sampai 0,5 . Penurunan berkisar antara $0,2-0,8$. Dilihat dari kreteria anemia pada responden anemia yang terbanyak adalah anemia ringan yaitu 25 orang dan pada $\mathrm{Hb}$ akhir anemia yang terbanyak juga anemia ringan sebanyak 25 orang.

Pengawas minum obat (PMO) tablet fe pada ibu hamil yang anemia sangat penting yang tujuan untuk meningkatkan kepatuhan ibu dalam mengkonsumsi tablet fe sehingga bisa bisa menaikan $\mathrm{Hb}$ ibu hamil dan angka kejadian anemia pada ibu hamil bisa diturunkan.kerterlibat tan keluarga (suami, ortu) sangat penting dalam pengawas minum obat tablet $\mathrm{Fe}$ sehinga bisa meninkatkan keinginan ibu untuk mengkonsumsi tablet fe.

Salah satu penyebab prevalensi anemia yang masih tinggi karna kurangnya kepatuhaan ibu hamil dalam mengkonsumsi tablet Fe. Niven (2002) menyebutkan bahwa salah satu faktor yang dapat mempengaruhi kepatuhaan penderita dalam menjalani pengobatan adalah dukungan keluarga, dukungan keluarga 
berupa mengingatkan minum obat, memberi motivasi.

Tablet Fe selama kehamilan sangat penting karena dapat membantu proses pembentukan darah merah yang membawa oksigen kedalam darah sehingga tidak menyebab kan anemia.Tubuh mengalami perubahan yang signifikan saat hamil. Jumlah darah meningkat $20-30 \%$. Sehinngga memerlukan peningkatan kebutuhaan pasokan besi dan vitamin untuk membuat Haemoglobin.Jika tubuh tidak memiliki cukup zat besi tubuh tidak dapat membuat sel - sel darah merah yang di butuhkan (Proverawati, 20011)

Metabolisme zat besi dalam tubuh manusia berfungsi untuk sintesis protein yang membawa oksigen, yaitu hemoglobin serta mioglobin dalam tubuh dan untuk sintesis enzim yamg memgandung zat besi dan turut serta dalam reaksi perpindahaan elektron serta reaksi oksidasi - reduksi. Penyerapan terjadih diduodenum, zat besi dalam bentuk ferro lebih mudah diserap dalam mukosa usus bila kondisi makanan menyebabkan reaksi asam dan bersifat mereduksi ,ferri akan menjadih ferro sehingga manjadih lebih mudah diserap disel usus ,kemudian zat besi yang diserap dibawa melalui membran mukosa serta serosa kedalam darah,protein pembawa (transferin) yang ada didalam plasma mengangkut kedalam sel atau ke Sumsum tulang bagi keperluan eritroposis (Gibney, dkk.2008).

Penelitian Maisa (2010), menyatakan bahwa hasil analisis hubungan keluarga dengan kepatuhan ibu hamil dalam mengkonsumsi tablet $\mathrm{Fe}$ dipuskesmas nangalo kota padang diperoleh bahwa ada sebanyak $8(61, \%)$ ibu dengan dukungan keluarga yang tinggi mempunyai kepatuhan konsumsi penuh. Sedang kan diantara ibu dengan dukungan keluarga rendah ,hanya $1(5,3 \%)$ yang mempunyai kepatuhan yang penuh.

Menurut Alabdin,dkk (2010) yang melakukan Penelitian dirumah sakit di Riyadh mendapatkan data ibu hamil yan rutin meminum tablet Fe selama Trimester
II dan II kadar Hbnya meningkat sebesar $0,3 \mathrm{gr} / \mathrm{dl}$. Sementara yang tidak patuh kadar Hbnya menurun signifika sekitar 1,4 gr $/ \%$.

Untuk meningkatkan kepatuhan ibu dalam mengkonsumsi tablet Fe. Petugas kesehatan harus mengikutsertakan keluarga dalam pengawasan Minum Obat terutama suami, keterlibatan suami semenjak awal akan sangat berguna untuk menjaga secara emosional merasa tenang dan yakin, terlebih jika setiap keluarga mengharapkan kehamilan, mendukung bahkan memperlihatkan dukungan dalam berbagai hal. Ibu hamil pun akan merasa lebih percaya diri, lebih bahagia selama menjalani kehamilan (Maulana,2010)

\section{KESIMPULAN DAN SARAN}

Dalam melibat kan keluarga sebagai PMO tablet $\mathrm{Fe}$ ternyata dapat meningkatkan kepatuhan ibu dalam mengkonsumsi $\mathrm{Fe}$ ,sehingga dapat meningkatkan kenaikan $\mathrm{Hb}$ ibu hamil dan angka kenjadian anemia dapat diturunkan.

\section{Saran}

1. Diharapkan bagi profesi keperawatan khususnya perawat yang bekerja dikomonitas agar mengikutsertakan keluarga dalam pengawasan minum Tablet Fe

2. Diharapkan bagi insitusi Dinas Kesehatan/Puskesmas membuat suatu program tentang PMO tablet Fe yang melibatkan dukungan keluarga dalam memantau ibu hamil anemia dalam mengkonsumsi Fe selama kehamila

3. Diharapkan bagi bidan desa pembina wilayah melakukan pendekatan yang maksimal pada keluarga ibu hamil dalam pengawasan minum obat $\mathrm{Fe}$ sehingga angka anemia dapat diturunkan

4. Bagi peneliti sendiri diharapkan bisa memberi masukan bagi instusi kesehatan lainnya tentang manfaat PMO. Dalam meningkatkan kepatuhan ibu hamil dalam mengkonsumsi Fe. Sehingga Prefalesi anemia bisa diturunkan. Dan manfaat 
lain yang peneliti harapkan nanti

dilapangan, peneliti bisa

menerapkannya ditempat kerja

sehingga bermanfaat bagi orang lain.

\section{DAFTAR PUSTAKA}

Arisman. (2009). Gizi dalam daur kehidupan. Jakarta : EGC

Bakta, I. (2006). Haematologi klinik ringkas. Jakarta : EGC

Depkes RI (2007). Gizi seimbang menuju sehat bagi ibu hamil dan ibu menyusui

Gibney, M J, dkk. (2008). Gizi kesehatan masyarakat. Jakarta: EGC

Proverawati, A. (2011). Anemia dan anemia kehamilan. Yogyakarta: Nuha Medika.

Yone, A (2010). Konsep ibu hamil pada trimester II. Di akses pada tanggal $11 \quad$ September 2011. http//riathaya.word press.com / 2010 / 05 / 08 konsep -ibu - hamil - pada - trimester - iii

Depkes RI (2001). Program penanggulangan anemia dan gizi Pada wanita usia

Depkes RI (2005). Anemia gizi dan tablet tambah darah (ttd) untuk wanita usia subur. Jakarta : Direktorat Kesehatan Mayarakat 